\title{
THE ORIGIN AND EARLY RADIATION OF TERRESTRIAL VERTEBRATES
}

\author{
ROBERT L. CARROLL \\ Redpath Museum, McGill University, 859 Sherbrooke St. West, Montreal, H3A 2K6, < robertC@Shared1.Lan.McGill.Ca>
}

\begin{abstract}
The origin of tetrapods from sarcopterygian fish in the Late Devonian is one of the best known major transitions in the history of vertebrates. Unfortunately, extensive gaps in the fossil record of the Lower Carboniferous and Triassic make it very difficult to establish the nature of relationships among Paleozoic tetrapods, or their specific affinities with modern amphibians. The major lineages of Paleozoic labyrinthodonts and lepospondyls are not adequately known until after a 20-30 m.y. gap in the Early Carboniferous fossil record, by which time they were highly divergent in anatomy, ways of life, and patterns of development. An even wider temporal and morphological gap separates modern amphibians from any plausible Permo-Carboniferous ancestors. The oldest known caecilian shows numerous synapomorphies with the lepospondyl microsaur Rhynchonkos. Adult anatomy and patterns of development in frogs and salamanders support their origin from different families of dissorophoid labyrinthodonts. The ancestry of amniotes apparently lies among very early anthracosaurs.
\end{abstract}

\section{INTRODUCTION}

$\mathbf{T}$ HE EMERGENCE of terrestrial vertebrates from fish in the Late Devonian was one of the most significant events in the history of life. By the mid- to Late Carboniferous, the lineages leading to modern amphibians and the ancestors of reptiles, birds, and mammals had differentiated. These events serve as informative models for the study of other major transitions and large scale radiations, but they also point to the problems of the incomplete nature of the fossil record and the difficulties of establishing relationships.

It is especially difficult to classify early tetrapods because their origin and early radiation occurred within several distinct environments, having different likelihoods of preservation in the sedimentary record. The immediate ancestors of amphibians were osteolepiform fish, which were common in near shore marine to estuarine environments that left an extensive sedimentary record. The oldest known (latest Devonian) amphibians were also widespread at the margins of marine environments. In contrast, very few fossils are known from the succeeding 20 to 30 m.y. of amphibian evolution, during which time ancestral tetrapods adapted to life in shallow fresh water and radiated into more fully terrestrial environments. This gap in the fossil record can be attributed to the much lower probability of preservation. Freshwater deposits are always much less likely to be preserved in the sedimentary record, both because they occupied much less surface area than marine deposits, but also because lakes, ponds, and rivers persist for much briefer periods of time. The ox-bow lake deposits of the Carboniferous coal-swamps, which have a particularly rich amphibian fauna, are each estimated to have lasted no more than about 10,000 years (DiMichele and Hook, 1992). Animals living away from the main water courses are even less likely to leave an informative fossil record.

\section{THE ORIGIN OF TETRAPODS}

We are fortunate in having an exceptionally good fossil record of osteolepiform fish from the Middle and Late Devonian of many parts of the world (Long, 1993; Ahlberg and Johanson, 1998). Although fishlike in general body form (Fig. 1.1, 1.2), members of this group can be allied with Late Devonian and Carboniferous tetrapods on the basis of numerous synapomorphies of the skull, vertebrae, and appendicular skeleton (Clack, 2000). Unlike any other group of fish, they possess internal nostrils, like those of all tetrapods. The pattern of bones of the skull roof are more similar to those of early tetrapods than are those of any other group of lobefinned fish, and the configuration of the proximal limb bones can be directly compared with the humerus, ulna, and radius of the forelimb, and the femur, tibia, and fibula of the hind limb.
More distal elements can be compared with the proximal bones of the wrist and ankle.

The most tetrapod-like of the osteolepiforms is Panderichthys, which has lost the dorsal and anal fins as well as the dorsal and ventral lobes of the caudal fin, presumably in relationship with adaptation to life in very shallow water. The margins of the orbits are raised above the general surface of the skull. The most important change between Panderichthys and early amphibians is the modification of the paired fins into tetrapod limbs (Fig. 1.3). Following Darwin (1859), such changes have long been hypothesized as resulting from selection among naturally occurring genetic variations.

It has only been within the last $15 \mathrm{yr}$ that discoveries in molecular genetics have revealed the nature of master control genes that influence the development of major structural features of metazoans (Gehring, 1998). Based on developmental differences observed in modern species, it is now possible to understand how these difference have evolved and so to explain how major morphological changes have occurred. The origin of fingers and toes in early tetrapods can be associated with changes in the expression of the Hox genes that regulate development of the body axis and appendages (Shubin et al., 1997). In modern ray-finned fishes, Hox genes $d 9$ to $d 13$ are expressed in an overlapping, linear sequence from the proximal to the distal end of the limb, along its posterior surface. Tetrapods differ in the extension of the area of expression of the most distal gene, Hoxd-13, so that it occupies a more anterior position along the entire distal end of the limb, in the position where the fingers and toes will form (Fig. 2). This can be associated with the distal extension of the limb and the formation of digits in an posterior to anterior sequence in most land vertebrates.

While it was apparently changes in the timing and position of gene expression that enabled the fins to achieve the form of a primitive tetrapod limb, there must have been a long term selective advantage for the formation of distinct digits rather than a broad fin for the prototetrapod with this genetic pattern to have survived and propagated. The skull of Panderichthys is truly intermediate between those of fish and tetrapods in its proportions and degree of integration of originally separate bones (Carroll, 1996). Unfortunately, no fossil is yet known that shows an intermediate structure between that of a fish fin and the tetrapod limb, but disarticulated skeletal elements are known from Late Devonian deposits that indicate the possibility for the discovery of truly intermediate structures during this time interval. Although these animals are not well known, differences in the size and proportions of the skull indicate a modest adaptive radiation during the transition between obligatorily aquatic fish and facultatively terrestrial amphibians, which occupied a period of approximately 15 m.y. (Ahlberg, 1991, 1995). 

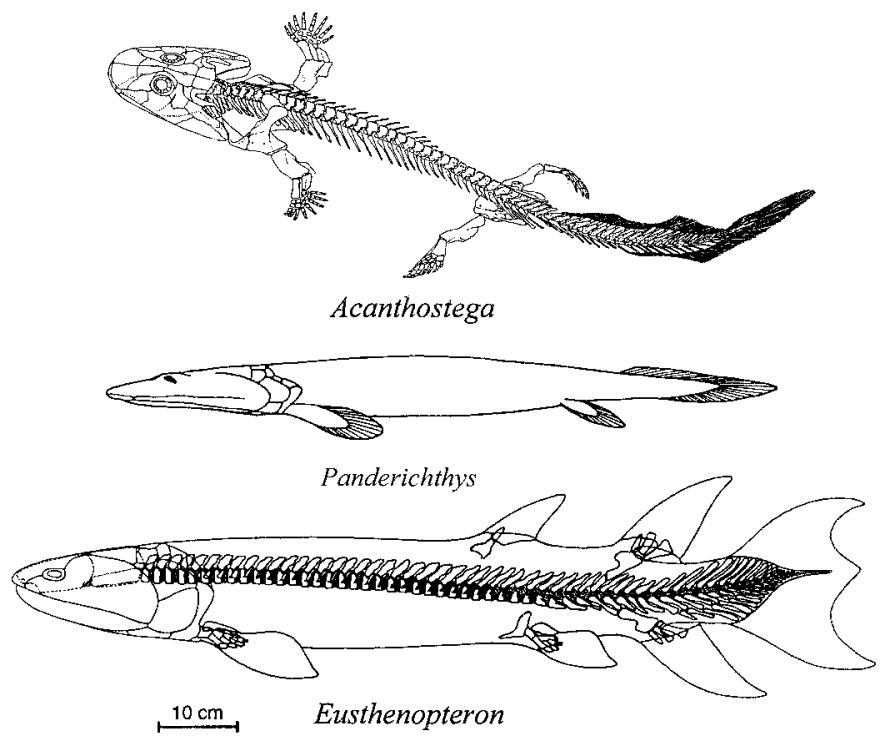

FIGURE 1 -The transition between osteolepiform fish and primitive amphibians represented by Eusthenopteron and Panderichthys from the Frasnian and Acanthostega from the Famennian (Upper Devonian), a period of approximately 15 m.y. Eusthenopteron and Panderichthys from Carroll (1997), Acanthostega from Coates (1996).

Knowledge of the entire skeleton of advanced osteolepiform fish and Upper Devonian tetrapods shows that rates of change vary greatly among the various parts of the body (Clack, 2000). However, even the most rapid changes, seen in the limbs, ribs, and braincase, may have occurred no more rapidly than those that have been measured within well known lineages of Cenozoic mammals. The total amount of morphological change in this transition can be accounted for by rates of evolution, estimated for the time span between generations, that are far slower than those recorded in modern populations (Gingerich, 1993; Lofsvold, 1988). As is the case for other major transitions that are adequately known from the fossil record, it is not necessary to hypothesize especially high rates of change in the fish-amphibian transition, but only that the direction of selection and so the direction of change are relatively constant, rather than rapidly fluctuating, as is usually the case during most of the evolutionary history of individual clades. What distinguish the long-term changes in the origin of tetrapods were the many selective factors associated with the shift in environment from sea to fresh water and onto land. These included locomotion, support, feeding, respiration, the sensory apparatus, and reproduction. All changed in the long run, but the rate and time of change varied greatly from system to system and from lineage to lineage. The structure of the limbs and ribs changed early and rapidly, the pattern of the skull bones changed more slowly and irregularly, and a fully terrestrial mode of reproduction only evolved in one lineage - that leading to amniotes-long after the changes in the skeletal anatomy and way of life of the adults.

\section{DEVONIAN AND PRIMITIVE CARBONIFEROUS AMPHIBIANS}

Upper Devonian amphibians were diverse, both structurally and in terms of geographical distribution, being known from Scotland (Ahlberg, 1998), central Russia (Lebedev and Coates, 1995), Latvia (Ahlberg et al., 1994) eastern United States (Daeschler et al., 1994) and Australia (Campbell and Bell, 1977). The best known are Ichthyostega and Acanthostega from East Greenland (Clack, 2000). These animals, approaching a meter in length, have more digits than any later tetrapods (from 6 to 8 on each limb), but the

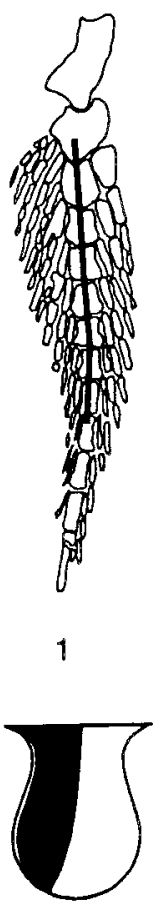

4
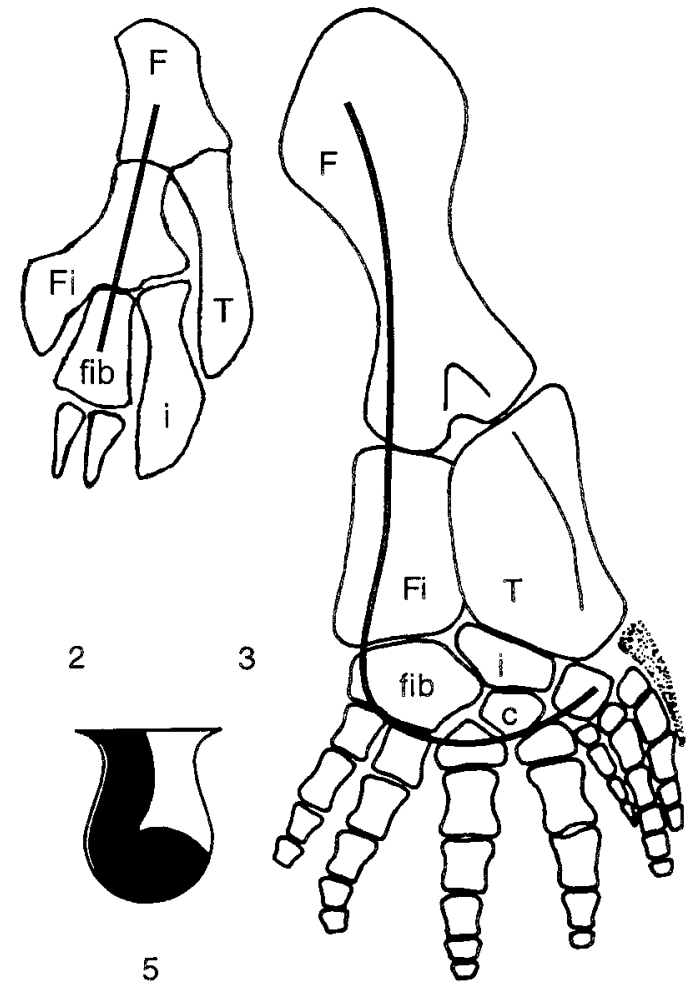

FIGURE 2-Changes in the axis of development and the expression of Hox genes between bony fish and tetrapods. 1, endochondral bones of the limb of a modern lungfish, showing both preaxial (anterior) and postaxial (posterior) radials, extending from the main axis of development; 2, limb bones of the osteolepiform fish Eusthenopteron, in which all radials are preaxial; 3 , hind limb of the early tetrapod Ichthyostega, in which the axis of development angles forward and the distal tarsals and digits develop in a posterior to anterior sequence; 4, area of expression of Hoxd 13 in the living zebra fish; 5, area of expression of Hoxd 13 in modern tetrapods. From Carroll (1997). Abbreviations: c-centrale; F-femur; Fi-fibula; fib-fibulare; i-intermedium; T-tibia.

limbs generally appear like those of most early amphibians. However, Clack and Coates (1995) stressed the presence of a very fish-like tail and the retention of gill supports suggestive of aquatic respiration to argue that these animals may have been largely aquatic in their habits, and suggested that "tetrapod" limbs may have evolved in primarily aquatic animals. Tulerpeton, from the Upper Devonian of Russia, is found in a deposit with a rich fauna of marine invertebrates. The presence of an Upper Devonian amphibian in Australia may have resulted from their extensive distribution via marine waters, along the coasts of the continents.

Following the very informative fossil record in the Late Devonian, there is a gap of 20 to $30 \mathrm{~m}$.y. before we have evidence of the initiation of the major tetrapod lineages of the mid- and Upper Carboniferous. Coates and Clack (1995) refer to this as "Romer's gap," in reference to Dr. Romer's long search for Early Carboniferous amphibians. This presumably represents a crucial period in the further penetration of vertebrates into a more strictly terrestrial environment.

Within the Lower Carboniferous and Namurian A, most of the known localities preserve a more or less uniform fauna, dominated by obligatorily aquatic amphibians and a diverse assemblage of fish (Carroll, 1994). In common with the Upper Devonian tetrapods, most retained lateral line canal grooves, and some lineages evolved an elongate trunk and diminutive limbs. These 
animals presumably retained the feeding patterns of their Devonian predecessors, with dependency on large, aquatic vertebrates. This environment was occupied by very similar species in what are now recognized as the continents of Europe, North America, and Australia. The Upper Devonian amphibians and many of their Lower Carboniferous descendants retained the relatively large size of their sarcopterygian predecessors. They may also have retained a mode of development similar to that of their fish ancestors.

No juvenile specimens of Panderichthys or any of the Upper Devonian amphibians have yet been discovered, but a long growth series, beginning with specimens $3 \mathrm{~cm}$ in length, has been described for the well known Frasnian osteolepiform Eusthenopteron (Cote et al., 2001). In contrast with modern amphibians, there is no evidence of a distinct larval stage. The juveniles resemble the adults in body proportions and lack external gills. There is no evidence of metamorphosis. A surprising feature is the direction of ossification of the vertebrae. In contrast with living tetrapods, which ossify the column from anterior to posterior, Eusthenopteron ossified from the tail forward, presumably because of the necessity for effective swimming at a very small size to catch prey and avoid predation. External gills would not have been necessary in well-aerated coastal waters. The retention of a long caudal fin in Ichthyostega and Acanthostega indicates emphasis on the tail for locomotion and suggests that they may have retained the sequence of vertebral ossification seen in Eusthenopteron.

\section{ADVANCED PALEOZOIC AMPHIBIANS}

It wasn't until approximately 30 m.y. after the appearance of amphibians in the Upper Devonian that fully terrestrial tetrapods, with well developed limbs and lacking lateral line canals in the adults, are known. In marked contrast with other Early Carboniferous deposits, the late Viséan locality of East Kirkton, near Edinburgh, Scotland, preserves a diverse fauna of primarily terrestrial amphibians (Rolfe et al., 1994). Although fish are common in some horizons, they do not occur in the tetrapod-bearing beds. Most of the amphibians can be assigned to major lineages that dominated the later Paleozoic, and presumably included close relatives of most of the living tetrapod clades. Not only are the adults of most of these animals clearly distinct from earlier taxa, but the immature specimens show evidence of different patterns of ontogenetic development, which distinguish major clades of more advanced tetrapods.

Labyrinthodonts.-By the late Viséan of East Kirkton, three major assemblages, not common in fully aquatic deposits, can be recognized-terrestrially adapted labyrinthodonts, lepospondyls, and a sister taxon of amniotes. All are differentiated by derived structures and/or patterns of development of the vertebrae. The most diverse assemblage are the labyrinthodonts, consisting of temnospondyls and anthracosaurs. They retained the relatively large size of their Late Devonian ancestors and the presence of multipartite vertebrae, which formed developmentally from paired neural arches, pleurocentra, and intercentra. Labyrinthodonts from the Upper Carboniferous and Permian had clearly distinguishable larval stages, termed branchiosaurs, with conspicuous external gills (Fig. 3) (Boy and Sues, 2000). In contrast with Eusthenopteron, vertebral ossification proceeded from anterior to posterior, suggesting less emphasis on caudal locomotion than on the limbs. The postcranial skeleton, and especially the vertebrae, carpals and tarsals, were very slow to ossify (Fig. 4.1). A juvenile specimen of the temnospondyl Balanerpeton from East Kirkton closely resembles later branchiosaurs (Milner and Sequeira, 1994).

We can only speculate on the sequence and timing of events leading to such a biphasic life history, during the roughly 30 m.y. since the Late Devonian. Clearly, reproduction in the earliest tetrapods occurred along the margins of the continents, in estuarine,
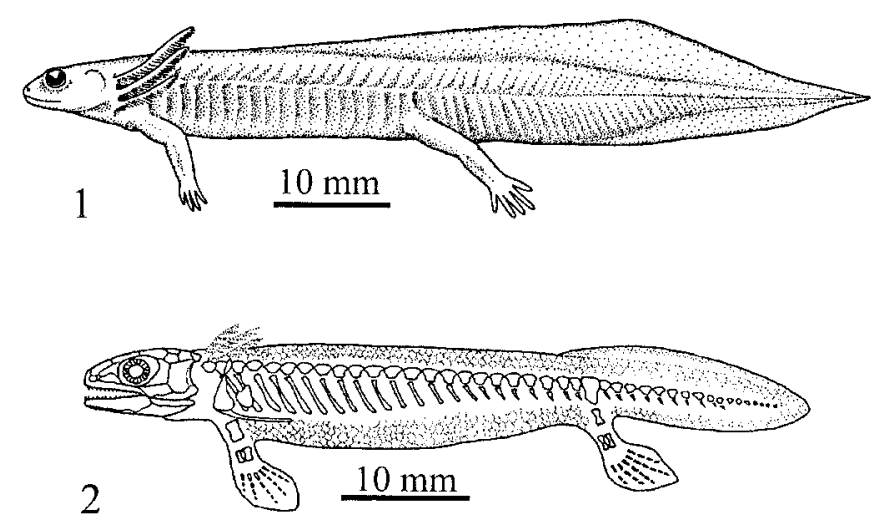

FIGURE 3-Larvae of labyrinthodonts. 1, Apateon, a temnospondyl larva, found by the thousands from Lower Permian beds in Europe (from Milner, 1982); 2, larva of the seymouriamorph Ariekanerpeton from the Lower Permian of Central Asia. The seymouriamorphs are typically placed within the Anthracosauroidea or Reptiliomorpha, with suggested affinities with amniotes (from Laurin, 2000).

brackish water environments, intermediate between the open sea and the marshes, deltas, and river mouths where fresh water was encountered.

East Kirkton, as well as many of the previously known Carboniferous localities, represent primarily quiet, partially isolated bodies of fresh water. These included vegetation-clogged ponds, coal swamps, and ox-bow lakes, which would have been commonly depleted in oxygen. This would have required the evolution of external gills in the relatively large larvae of both temnospondyl and anthracosaurian labyrinthodonts. The East Kirkton fauna lived within and around a moderately large lake, the water chemistry and temperature of which were influenced by local volcanic activity. The ephemeral nature of these bodies of water may have restricted the number of large aquatic predators. Both fish and tetrapods are known from East Kirkton, but they are always found in different horizons (Clarkson et al., 1994). The East Kirkton labyrinthodonts were amphibians in the modern sense, with obligatorily aquatic larvae, a more or less conspicuous metamorphosis, and a terrestrial adult stage.

Lepospondyls.- Two other groups are represented at East Kirkton whose later members lack distinct larval stages, and show no evidence of external gills. Both are characterized by rapid ossification of the vertebrae at a small body size. The lepospondyls are represented by the aïstopods, which were already highly specialized in the fenestration of the skull, the great elongation of the vertebral column, and the complete loss of limbs (A. C. Milner, 1994). The distinctive nature of the lepospondyls was initially recognized by Zittel (1890), based on the presence of cylindrical centra, fused to the neural arches, in contrast with the multipartite vertebrae of labyrinthodonts.

Adult lepospondyls are most clearly distinguished from labyrinthodonts by their small body size. Labyrinthodonts show a very wide range of skull sizes, from $5 \mathrm{~cm}$ to $50 \mathrm{~cm}$, while most lepospondyls had a skull length of $2 \mathrm{~cm}$ to $3 \mathrm{~cm}$, with little overlap between the sizes of the two groups (Fig. 5). Small size is most plausibly interpreted as an adaptation to feeding on small prey, such as the burgeoning population of small adult insects and other fresh water and terrestrial arthropods. Many of the anatomical features that distinguish the lepospondyl orders from labyrinthodonts and from one another can be attributed to miniaturization and paedomorphosis - the retention of juvenile traits into the adult. Structures such as labyrinthodont infolding of the dentine, that only appear late in labyrinthodont ontogeny, are seen in only 

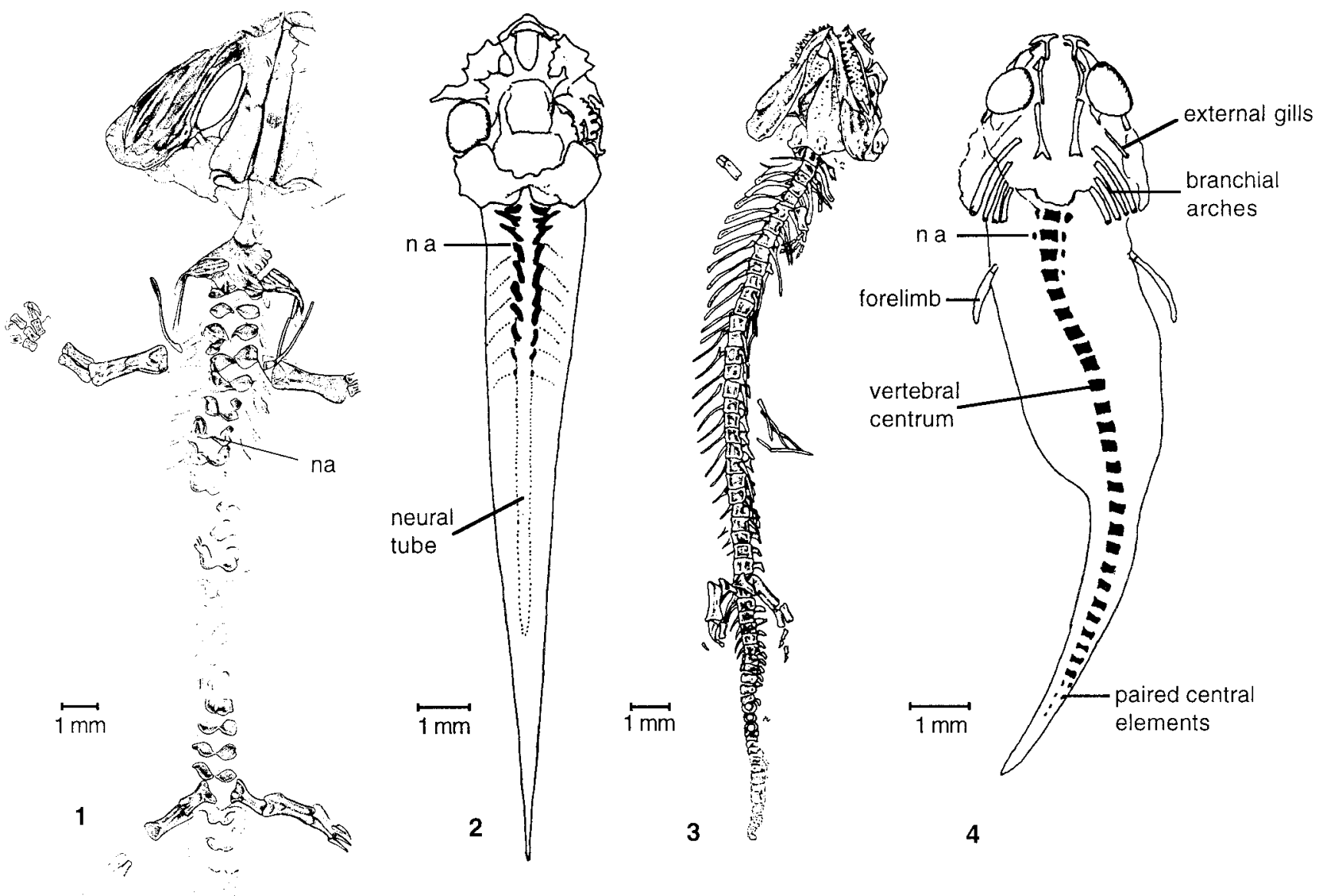

FIGURE 4-Patterns of vertebral development in Paleozoic and modern amphibians. 1, branchiosaur, in which the neural arches ossify long before the centra, in an anterior to posterior direction, with the caudal vertebrae being the last to develop; 2, larval frog, Rana pipiens, in which the arches are chondrified, but there is no trace of centra. No elements of the vertebrae develop in the tail; 3 , the Carboniferous microsaur Hyloplesion, in which cylindrical centra are ossified in the tail of the smallest specimens known; 4, the primitive living salamander Salamandrella, in which cylindrical centra extend into the tail, but only a few neural arches are chondrified at the very front of the column. Abbreviation: na-neural arch. From Carroll et al. (1999).

the very largest lepospondyls. Individual skull bones and other anatomical features that are late to develop in labyrinthodonts are variably lost in lepospondyls. Hanken (1984) showed that miniaturization in salamanders can be attributed to hyperossification at small size, which, by analogy with lepospondyls, also explains the formation of cylindrical centra and their frequent fusion with the neural arches at a very small size.

The lepospondyls were an extremely varied assemblage including the limbless aïstopods and adelogyrinids, the newtlike nectrideans (all of which have long, laterally compressed tails), the lysorophids, with extremely fenestrate skulls and elongate trunks but retaining rudimentary limbs, and the salamander- to lizardlike microsaurs, with solidly roofed skulls and typically retaining well developed limbs (Fig. 6). Although no external gills or obviously larval stages have been recognized among this assemblage, members of several groups had lateral line canal grooves and others retained a ossified hyoid apparatus, indicative of aquatic feeding and respiration. It is assumed that lepospondyls were physiologically amphibians in lacking the extraembryonic membranes of amniotes and laying their eggs in the water. Only a single group of lepospondyls is known from East Kirkton, the aïstopods, but these were the most highly specialized members of the entire assemblage. The adelogyrinids, microsaurs, nectrideans, and lysorophids appear in the fossil record progressively during the middle portion of the Carboniferous.

Amniotes.-Clearly distinct from the labyrinthodonts and lepospondyls of the East Kirkton fauna is the genus Westlothiana (Smithson et al., 1994) that appears to be a sister-taxon of the amniotes, which became clearly distinguishable by the midPennsylvanian. In common with lepospondyls, Westlothiana shows precocial ossification of the vertebrae at a small size. However, more specific features of the vertebrae, including the retention of large intercentra, as well as the structure of the well ossified tarsus and the pattern of the bones of the skull table, 


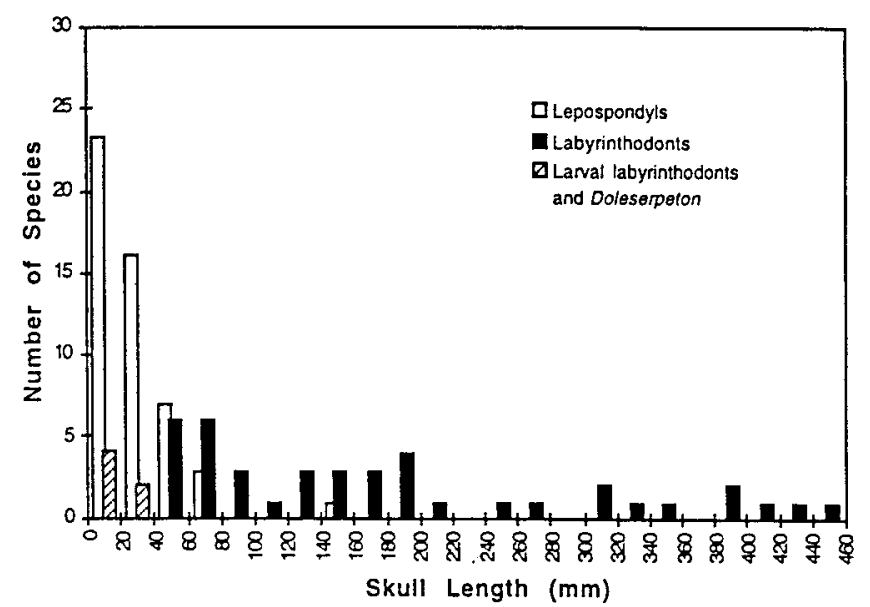

FiguRE 5-Size distribution of cranial length in Paleozoic amphibians. Open bars: lepospondyls. Solid bars: adult labyrinthodonts. Hatched bars: larval, possibly neotenic branchiosaurs and Doleserpeton; these are strongly supported candidates for the sister-taxa of frogs and salamanders. From Carroll (1999). point to amniotes rather than any lepospondyls as close sistertaxa (Carroll, 1991).

Paton, Smithson, and Clack (1999) described an even earlier species, Casineria kiddi, from the Cheese Bay Shrimp Bed of Scotland, with highly ossified vertebrae and a five-toed manus resembling those of early amniotes, suggesting a very early divergence of this lineage from other descendants of the Paleozoic tetrapod assemblage. The structure of the manus in Casianeria, the foot of Westlothiana, and the vertebrae of both genera, suggest affinities with anthracosaurs, although neither is sufficiently complete for an effective cladistic analysis.

In contrast with the modern amphibian orders, which are not recognizable until the Jurassic, ancestors of the modern reptiles, birds, and mammals, are known from the Upper Carboniferous (Carroll, 1982). The ancestral amniotes were small animals, superficially resembling primitive, insectivorous lizards. Most early amniote fossils were preserved under conditions indicative of a fully terrestrial way of life. The oldest of all were found in upright stumps of the lycopod Sigillaria, a place of burial that could only be reached by land animals (Carroll, 1964, 1969).

The rarity of older terrestrial deposits has limited our knowledge of their specific relationships among earlier tetrapods. Like the origin of the many lineages of lepospondyls, that of the amniotes was certainly associated with miniaturization and hyperossification. Like lepospondyls, early amniotes ossify fully cylindrical centra at a very small size, but unlike most members of
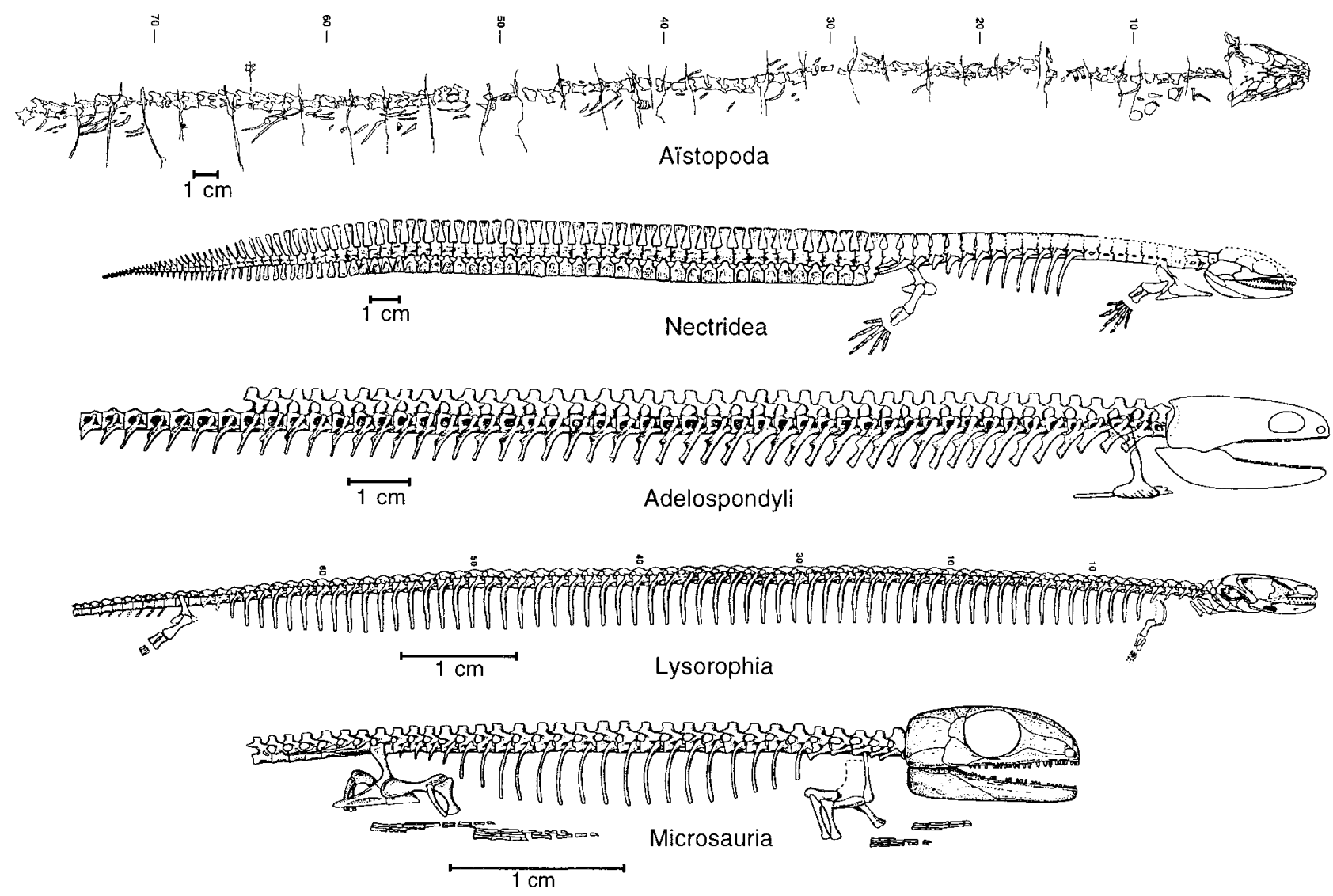

FIGURE 6-Reconstructions of the skeletons of the earliest and most primitive adequately known species of the five major clades of lepospondyls. The Aïstopoda is represented by Lethiscus stocki from the Mid-Viséan, Lower Carboniferous, of Scotland. The Nectridea is represented by Urocordylus wandesfordii, Westphalian A, Upper Carboniferous, Ireland. The Adelospondyli by Palaeomolgophis scoticus, Viséan of Scotland. The lysorophid is Brachydectes newberryi, Westphalian D, Upper Carboniferous, Ohio. The microsaur is Utaherpeton franklini, lower portion of Upper Carboniferous, Utah. Illustrations modified from Carroll et al. (1998). 
that group, the intercentra remain large throughout the trunk region. The most important other feature of the vertebrae is the retention of a multipartite atlas-axis complex, which allowed controlled movement of the head in all planes. No lepospondyl has more than one element of the atlas centrum, and in most orders movement is limited to hinging in the vertical plane.

The problems of classification.-The sudden appearance of several major groups of tetrapods in the late Viséan makes it difficult to establish their interrelationships and thus those of their descendants, which include the ancestors of all modern tetrapods (Fig. 7).

Of all the lineages known from East Kirkton and other mid- to Late Carboniferous deposits, only one, the anthracosaurs or reptiliomorphs, appears to show specific affinities with any of the Upper Devonian tetrapods. Bones attributed to Tulerpeton (Lebedev and Coates, 1995) from central Russia retain primitive cranial features, including an intertemporal bone and mobility between the skull table and cheek, that are shared with later anthracosaurs but not with the very diverse temnospondyls. Isolated humeri from the earliest known Carboniferous locality of Horton Bluff are appropriate intermediates between those of Tulerpeton and later anthracosaurs (Clack and Carroll, 2000), but both Acanthostega (Coates, 1996) and Ichthyostega (Jarvik, 1996) have numerous autapomorphies that preclude close comparison with any other Paleozoic tetrapods. Among Paleozoic amphibians, only anthracosaurs share significant similarities with amniotes, but even the earliest known stem amniote, Casineria, is too highly derived for detailed comparison.

Most Paleozoic labyrinthodonts belong to the Temnospondyli (Holmes, 2000). They appear to be monophyletic in origin, but their specific relationships to Upper Devonian or other Carboniferous labyrinthodonts remain uncertain. Many Carboniferous temnospondyls appear to have been primarily terrestrial in habits, with strong limbs, but no lateral line canals. On the other hand, numerous lineages returned to a more amphibious way of life. This was carried to its extreme within a major secondary radiation, beginning in the Late Permian and continuing into the Early Cretaceous - the stereospondyls (Warren, 2000).

All of the taxa grouped as lepospondyls are highly derived when they first appear in the fossil record, with no plausible intermediates between them and any other groups of Paleozoic tetrapods. Many attempts have been made to classify the lepospondyls, using both cladistic analysis and other means (Carroll, 1995; Carroll and Chorn, 1995; Carroll et al., 1998; Laurin and Reisz, 1997; Anderson, 2001), but the disparity of the resulting cladograms is too great to give any of them credence. Relationships of lepospondyls among one another, and with any of the labyrinthodont groups can only be established on the basis of new discoveries of fossil from the Lower Carboniferous that show intermediate morphologies.

\section{THE ANCESTRY OF THE MODERN AMPHIBIAN ORDERS}

Most Carboniferous tetrapods have been classified among the amphibians, yet none is an obvious relative of the modern frogs, salamanders, and caecilians (poorly known, elongate, limbless animals of the wet tropics). The oldest known fossils that are assuredly assigned to these orders are from the Lower and Middle Jurassic, separated by a gap in the fossil record of approximately 100 m.y. from any plausible Paleozoic ancestors. The oldest known frogs are structurally similar to modern genera, with the rear limbs and pelvic girdle already highly specialized for jumping (Jenkins and Shubin, 1998). Middle Jurassic salamanders are more primitive than members of the modern families, but unequivocally belong to the Urodela (Milner, 2000). Upper Jurassic salamanders from China closely resemble living hynobiids and cryptobranchids (Gao and Shubin, 2001). Although still retaining tiny limbs, the Lower Jurassic caecilian Eocaecilia is already elongate, and the skull and lower jaws show many of the highly derived characters that contribute to the unique jaw closing apparatus of living genera (Jenkins and Walsh, 1993; Carroll, 2000).

Although it is generally believed that the three orders had a unique common ancestry distinct from that of amniotes, no known fossil can be recognized as an immediate common ancestor, nor a plausible sister-taxon of such a group. Radically different taxa have been proposed as putative sister-groups. Most studies support ancestry among the temnospondyl amphibians, specifically among the families Amphibamidae and Branchiosauridae (e.g., Bolt, 1969, 1991; A. R. Milner, 1993, 2000), but Laurin and Reisz (1997) hypothesized the Lysorophia among the lepospondyls as the closest sister-taxon (Fig. 6). The Lysorophia shares some characters with each of the three groups: greatly elongate body with much reduced limbs in common with the earliest known caecilian, a fenestrate skull, vaguely comparable with those of frogs and salamanders, and loss of many similar skull bones, but the total configuration is that of a chimera that has no unique derived characters in common with any of the individual orders.

Although numerous individual characters, including pedicellate teeth, cutaneous respiration, green glands, and other aspects of the soft anatomy are found in all three orders, most features of their anatomy and way of life are highly divergent, notably their manner of locomotion and the nature of their larvae. Whatever their ultimate common ancestry, each order must have had a long period of independent evolution, going back into the Carboniferous. Rather than trying to find an immediate common ancestor, the approach taken here will be to look for the most plausible ancestry of each order separately. If a similar ancestry is discovered for all three, then this will demonstrate the likelihood of an immediate common origin.

Caecilia.-The recent discovery of numerous, well-preserved caecilians from the Lower Jurassic of Arizona provides a strong basis for establishing their relationships with Paleozoic amphibians (Jenkins and Walsh, 1993; Carroll, 2000; Jenkins, Walsh, and Carroll, MS in prep.). This genus, Eocaecilia (Fig. 8.1) closely resembles recent caecilians in the general configuration of the skull, specifically the unique and highly derived configuration of the lower jaw indicative of the use of the interhyoideus posterior as the primary jaw closing muscle. The trunk was already greatly elongated, although much reduced fore and hind limbs were retained. The closest resemblance among Paleozoic amphibians lies with the lepospondyl microsaur Rhynchonkos, which has a very similar skull, elongate trunk, and small limbs (Fig. 8.2). If we limit our consideration to caecilians, certainly their most parsimonious origin is from this microsaur. Neither Eocaecilia nor Rhynchonkos have any features bearing on the origin of either frogs or salamanders. In particular, the skull roof is complete, without an orbitotemporal opening, and there are large postparietal bones, missing in all later lissamphibians. Eocaecilia does, however possess pedicellate teeth, long considered a synapomorphy of the modern amphibian orders. They are not present in any microsaur.

Anura.-Frogs and salamanders share more similarities than either does with caecilians, but they are still highly divergent. In addition to differences in limb proportions, manner of locomotion, and the nature of their larvae, are the typical patterns of vertebral development. A late larval stage of the common frog Rana pipiens shows a series of paired, cartilaginous neural arches that form in an anterior to posterior sequence from the head to the sacrum (Fig. 4.2). This is followed by the formation of cartilaginous centra and the subsequent ossification of both elements. Representatives of all modern frog families that have been studied show a similar pattern of vertebral development (Carroll et al., 1999). A very similar pattern is seen in the development of vertebrae in Paleozoic branchiosaurs (Fig. 4.1). The slow appearance 


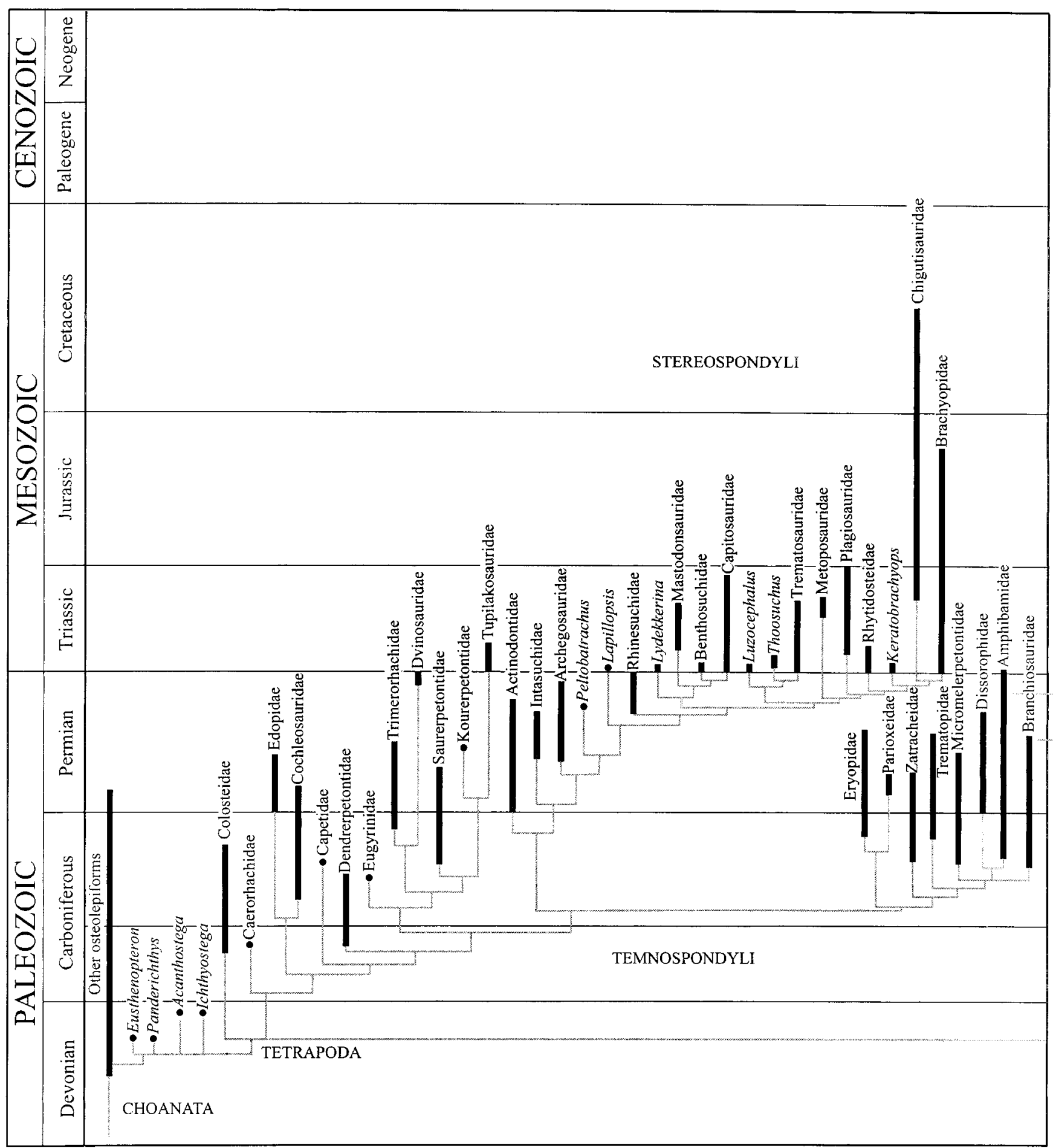

FIGURE 7-Phylogeny of the Amphibia based on data in Heatwole and Carroll (2000). Dark lines represent known fossil record at the family level. Gray lines indicate ghost lineages based on approximate duration of sister-taxa. The fossil record of modern amphibians is too incompletely known to give a reliable estimate of ghost lineages.

of the tail in branchiosaurs provides the mechanism for the absence of caudal vertebrae in tadpoles, which can be attributed simply to the delay and later cessation of chondrification and ossification behind the sacrum.

Close affinities between frogs and temnospondyls have long been assumed on the basis of the cranial similarities between most frogs and members of the temnospondyl families Dissorophidae and Amphibamidae, both of which have well-developed, froglike otic notches, and a stapedial structure strongly suggestive of an impedance matching middle ear. Doleserpeton, which Bolt $(1969,1991)$ hypothesized as ancestral to all three lissamphibian orders, has especially close resemblance to frogs 


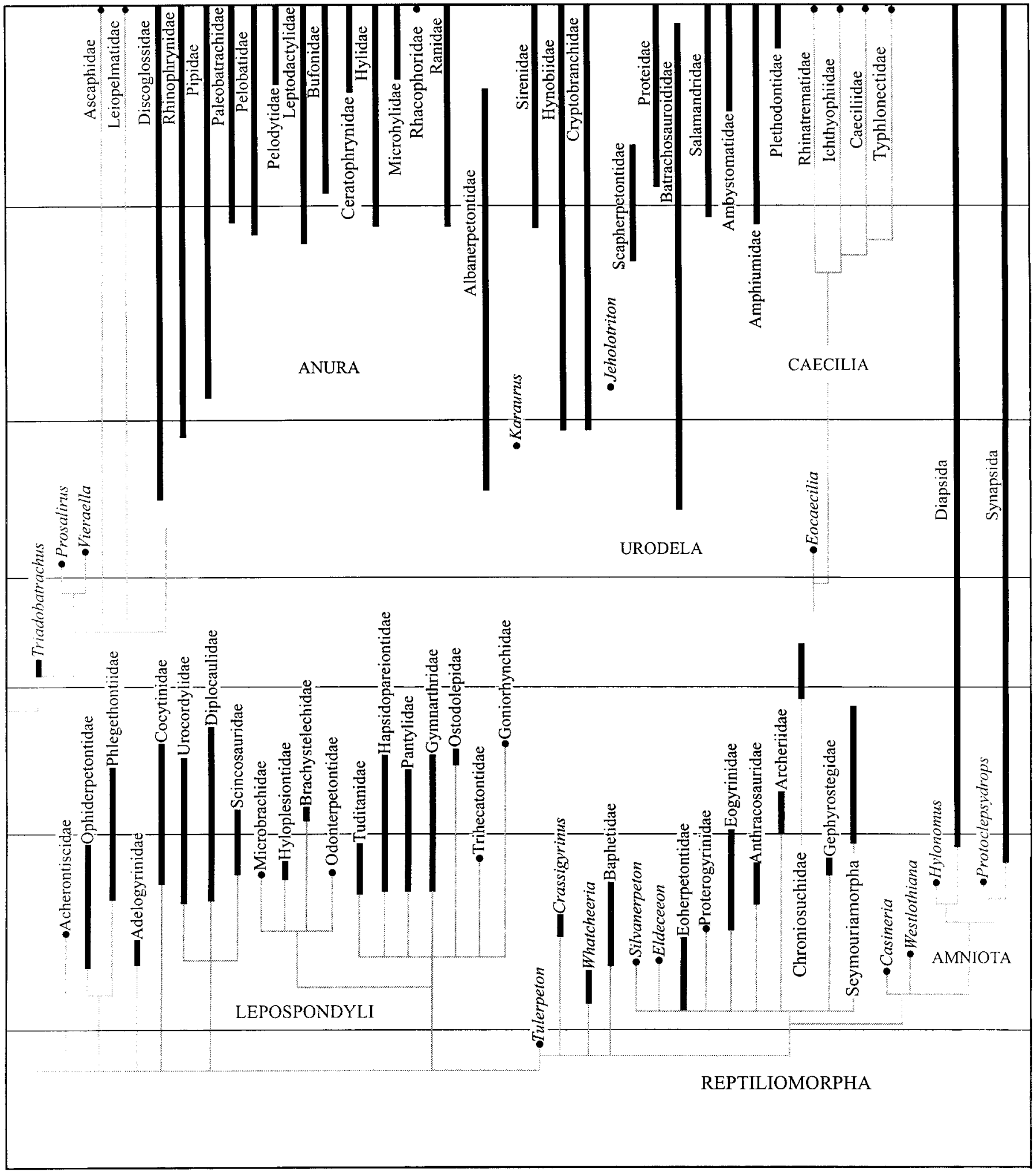

FIGURE 7-Continued. 

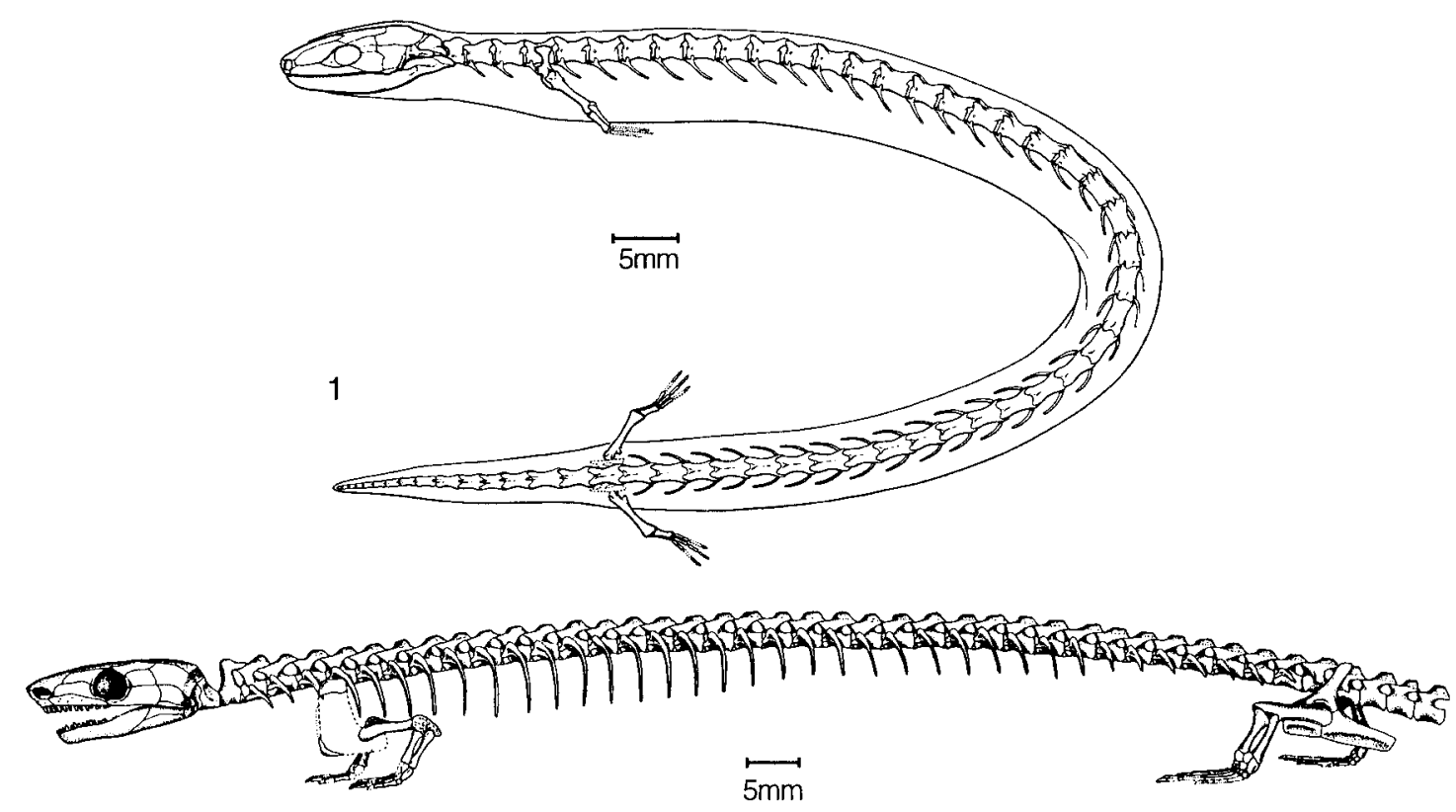

2

FIGURE 8-Comparison of caecilian and microsaur skeletons. 1, Reconstruction of the skeleton of the Lower Jurassic caecilian Eocaecilia, from Jenkins and Walsh (1993). 2, Reconstruction of the skeleton of the Lower Permian goniorhynchid microsaur Rhynchonkos, from Carroll and Gaskill (1978).

in the bicondylar articulating surface of the atlas, unlike that of any other Paleozoic temnospondyls, and the development of the trunk vertebrae, which pass ontogenetically from multipartite to a strong fusion between a cylindrical centrum and the neural arch.

Further confirmation of a temnospondyl origin for frogs is provided by the roughly intermediate anatomy of the Lower Triassic Triadobatrachus, which has a shortened trunk, a very small number of caudal vertebrae, and, most importantly, a forwardly angled iliac blade. The skull resembles that of modern frogs in the presence of conspicuous otic notches, a fused frontoparietal, and orbitotemporal openings. This establishes a protoanuran morphology as early as the Lower Triassic, with no obvious similarities with either salamanders or caecilians (Roček and Rage, 2000).

Caudata.-This leaves the salamanders as the only group without a clearly evident Paleozoic ancestry. After recognizing the very temnospondyl features of vertebral development in frogs, attention was focussed on their ontogeny in salamanders. Many salamanders including Salamandrella, a member of the most primitive family, Hynobiidae, show a very different pattern of development from that seen in frogs, with the centra forming well before the neural arches (Fig. 4.4). This is comparable to the pattern seen in lepospondyls, suggesting that salamanders might share a closer common ancestry with that group rather than with labyrinthodonts, indicating a very distinct origin from that of frogs.

Further investigation showed that vertebral development in salamanders was much more varied than that in frogs, with some salamanders, including the hynobiid Ranodon and the more derived Dicamptodon (Wake and Shubin, 1997) showing a typical anuran sequence. This opens up the possibility of a common ancestry from among temnospondyl labyrinthodonts. In fact, the larvae of modern salamanders show strong similarities with the branchiosaur larvae of labyrinthodonts. Figure 9 shows a branchiosaurid from the Lower Permian of Germany. It combines the presence of salamander-like external gills and well-developed limbs with a frog or labyrinthodont sequence of vertebral development, and a skull retaining an otic notch.

Other specimens show the area of the gill openings and associated "gill rakers," which closely resemble those of the larvae of modern salamanders, specifically Ambystoma (Fig. 10). There are six rows of individual denticles in branchiosaurids, interdigitating across the three gill slits like the teeth of a zipper. Research by Lauder and Schaffer (1985) showed that similar shaped "gill rakers" in Ambystoma are used to close the gill slits to form a more effective vacuum for drawing in prey when using gape and suck feeding. The pattern of denticles common to salamanders and branchiosaurids is clearly derived relative to that of all other temnospondyl families, in which non-interdigitating "gill rakers" arise from four rows of broad bony platelet associated with the ceratobranchials.

Frog tadpoles, known as early as the Early Cretaceous, have an entirely different feeding appartus than that of salamanders or branchiosaurs, specialized for suspension feeding on microscopic plant material. The proportions and structure of the limbs in branchiosaurids are also more similar to those of salamanders than they are to frogs, with both front and hind limbs present in the larvae, and of comparable size.

A major stumbling block to accepting a labyrinthodont origin for salamanders has been the fact that adult temnospondyls have a conspicuous otic notch, implying an impedance-matching middle ear. If salamanders evolved from branchiosaurids, we must assume that they had lost a prior capacity to detect high frequency, airborne vibrations. Most Lower Permian branchiosaurids are known from large lakes that were permanent on an ecological time scale. This suggests that selection may have acted to elaborate structures associated with aquatic feeding. If one compares the skulls and hyoid apparatus of branchiosaurids and salamanders, one sees a possible conflict between two functions of the cheek region-aquatic feeding and reception of air-borne sound. Most adult frogs have a large, air-filled middle ear chamber medial to the tympanum. The adductor muscles of the cheek region 


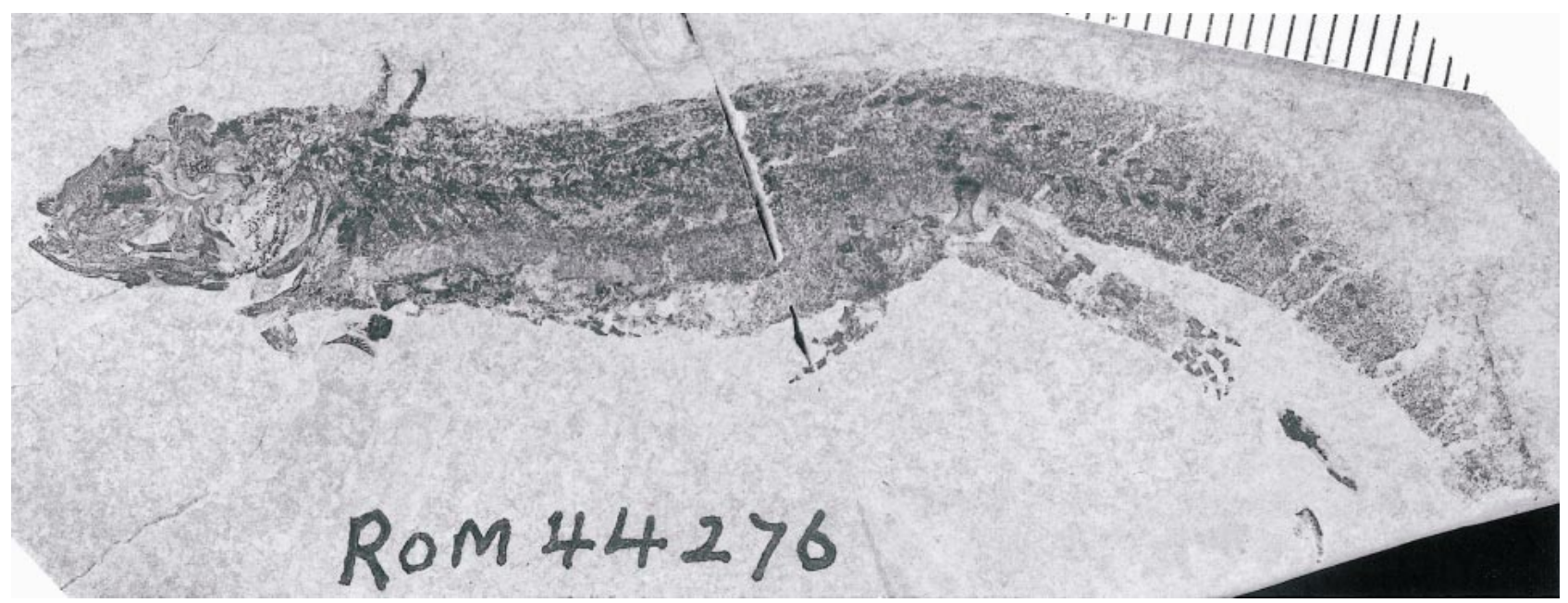

FIgure 9-Royal Ontario Museum, Toronto, Canada 44276, skeleton of a larval Branchiosauridae, Apateon Lower Permian, Rehborn, Germany. Scale bar in $1 \mathrm{~mm}$ intervals.
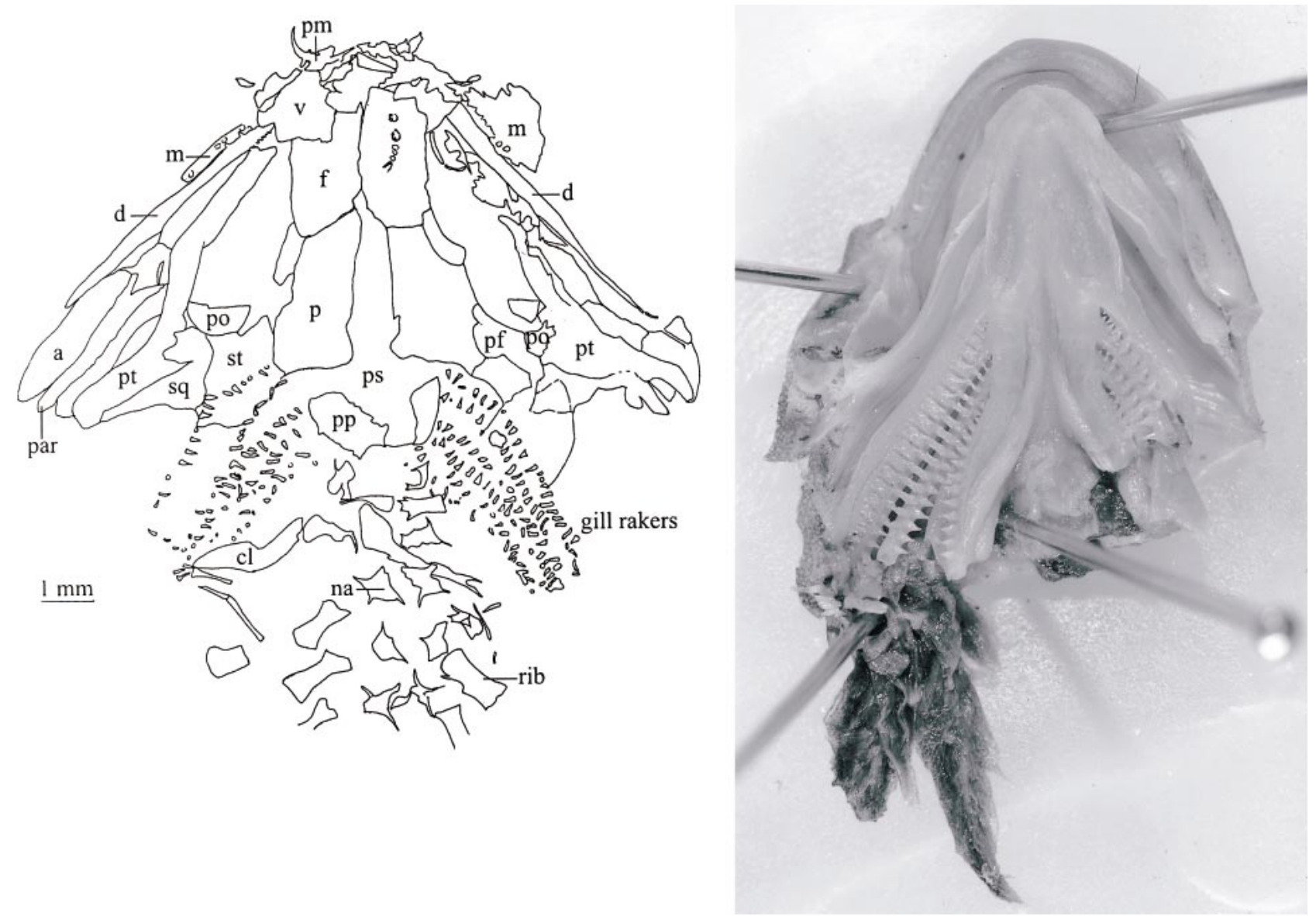

Figure 10-Left, Royal Ontario Museum, Toronto, Canada 44276, dorsal view of the skull of a branchiosaurid, Apateon Lower Permian, Rehborn, Germany. Right, dorsal view of the lower jaws and branchial region of Ambystoma tigrinum, Canadian Museum of Nature, Ottawa, Canada 7255, from 7.3 mi east of Spruce Grove, Alberta. Abbreviations: a—angular; cla—clavicle; $\mathrm{d}$-dentary; f—frontal; m-maxilla; na—neural arch; $\mathrm{p}$ parietal; par-prearticular; pf-postfrontal; pm—premaxilla; po—-postorbital; pp—postparietal; ps—parasphenoid; pt—pterygoid; sq—squamosal; st-supratemporal; v-vomer. 
are restricted to a small area, below and anterior to the middle ear. In the advanced larvae and adults of terrestrial salamanders, much of the region behind and somewhat medial to the cheek is occupied by the hyoid apparatus and the area within which the prey would be captured. The adductor jaw muscles completely cover the area lateral to where the tympanum is located in adult frogs. Branchiosaurids seem to show an intermediate condition, in that the squamosal still forms a notchlike posterior recess (although less well defined than in adult temnospondyls), but the stapes does not ossify fully.

Unfortunately, discussion of specific changes between branchiosaurids and primitive salamanders is largely speculative in the absence of any adequately known fossil representatives of the lineage leading to salamanders between the Lower Permian and the Middle Jurassic, a period of roughly 100 m.y. (Fig. 7). Clearly, we have a long way to go before we have adequate knowledge of the evolutionary history of any of the three living amphibian orders. If frogs and salamanders both evolved from temnospondyls, and amniotes from anthracosaurs, then these amphibian orders did have a more recent common ancestry than either had with amniotes. However, this leaves the question of the relationship of caecilians and microsaurs unresolved since there is no substantial evidence as to the specific origin of any of the lepospondyl orders. This can only be established with a more complete knowledge of fossils from the base of the Carboniferous.

\section{CONCLUSIONS}

We have a great deal of knowledge of the anatomy of a vast array of Paleozoic tetrapods (Heatwole and Carroll, 2000), but the specific interrelationships of the major taxa and their affinities with the modern orders remain impossible to establish with assurance without much more knowledge of fossils from the Lower Carboniferous and from the period between the Lower Permian and the Jurassic.

\section{ACKNOWLEDGMENTS}

Research for this paper was greatly assisted by numerous enthusiastic and dedicated McGill University undergraduates: K. Albright, L. Bar-Sagi, C. Boisvert, S. Cote, N. Gour, A. Kuntz, N. Philip, C. Rolian, and A. Taranko. C. Boisvert also assisted in preparing the illustrations. Other colleagues with whom I collaborated on this work include J. Bolt, R. Cloutier, F. Jenkins Jr., D. Walsh, and D. Green. H.-D. Sues contributed greatly by loaning branchiosaur material from the Royal Ontario Museum. Thanks are also extended to two reviewers, J. Clack and A. Milner. Financial support was provided by the Natural Sciences and Engineering Research Council of Canada.

\section{REFERENCES}

Ahlberg, P. E. 1991. Tetrapod or near-tetrapod frossils from the Upper Devonian of Scotland. Nature, 345:298-301.

AhlberG, P. E. 1995. Elginerpeton pancheni and the earliest tetrapod clade. Nature, 373:420-425.

Ahlberg, P. E. 1998. Postcranial stem tetrapod remains from the Devonian of Scat Craig, Morayshire, Scotland. Zoological Journal Linnean Society, London, 122:99-141.

Ahlberg, P. E., And Z. Johanson. 1998. Osteolepiforms and the ancestry of tetrapods. Nature, 395:792-794.

AhlberG, P. E., E. LuKŠEvics, AND O. Lebedev. 1994. The first tetrapod finds from the Devonian (Upper Famennian) of Latvia. Philosophical Transactions Royal Society London, B, 343:303-328.

Anderson, J. S. 2001. The phylogenetic trunk: maximal inclusion of taxa with missing data in an analysis of the Lepospondyli (Vertebrata, Tetrapoda). Systematic Biology, 50:170-193.

BoLT, J. R. 1969. Lissamphibian origins: possible protolissamphibians from the Lower Permian of Oklahoma. Science, 166:888-891.

BoLt, J. R. 1991. Lissamphibian origins, p. 194-222. In H.-P. Schultze and L. Trueb (eds.), Origins of the Higher Groups of Tetrapods: Controversy and Consensus. Cornell University Press, New York.

BOY, J. A., AND H.-D. SuEs. 2000. Branchiosaurs: larvae, metamorphosis and heterochrony in temnospondyls and seymouriamorphs, p. 11501197. In H. Heatwole and R. L. Carroll (eds.), Amphibian Biology, Volume 4, Palaeontology: The Evolutionary History of Amphibians. Surrey Beatty \& Sons, Chipping Norton, NSW, Australia, pp. 9731496.

Campbell, K. S. W., AND M. W. Bell. 1977. A primitive amphibian from the late Devonian of New South Wales. Alcheringa, 1:369-381.

CARroll, R. L. 1964. The earliest reptiles. Zoological Journal Linnean Society, 45:61-83.

Carroll, R. L. 1969. A Middle Pennsylvanian captorhinomorph and the interrelationships of primitive reptiles. Journal of Paleontology, 43: $141-170$.

CARroll, R. L. 1982. Early evolution of reptiles. Annual Review of Ecology and Systematics, 13:87-109.

CARroll, R. L. 1991. The origin of reptiles, p. 331-353. In H.-P. Schultze and L. Trueb (eds.), Origins of the Higher Groups of Tetrapods: Controversy and Consensus. Cornell University Press, New York.

CARroll, R. L. 1994. Evaluation of geological age and environmental factors in changing aspects of the terrestrial vertebrate fauna during the Carboniferous. Transactions of the Royal Society of Edinburgh: Earth Sciences, 84:427-431.

CARroll, R. L. 1995. Phylogenetic analysis of Paleozoic choanates. Bulletin du Muséum national d'historie naturelle, 17:389-445.

CARroll, R. L. 1996. Revealing the patterns of macroevolution. Nature, 381:19-20.

Carroll, R. L. 1997. Patterns and Processes of Vertebrate Evolution. Cambridge University Press, Cambridge, 448 p.

Carroll, R. L. 1999. Homology among divergent Paleozoic tetrapod clades, p. 47-64 In G. R. Bock and G. Cardew (eds.), Homology. Wiley, Chichester (Novartis Foundation Symposium 222).

CArroll, R. L. 2000. Eocaecilia and the origin of caecilians, p. 1402 1411. In H. Heatwole and R. L. Carroll (eds.), Amphibian Biology, Volume 4, Palaeontology: The Evolutionary History of Amphibians. Surrey Beatty \& Sons, Chipping Norton, NSW, Australia.

CARroll, R. L., AND J. ChORN. 1995. Vertebral development in the oldest microsaur and the problem of "lepospondyl" relationships. Journal of Vertebrate Paleontology, 15:37-56.

CARroll, R. L., AND P. Gaskill. 1978. The Order Microsauria. Memoirs of the American Philosophical Society, 126:1-211.

Carroll, R. L., A. Kuntz, and K. Albright. 1999. Vertebral development and amphibian evolution. Evolution \& Development, 1:36-48.

Carroll, R. L., K. A. Bossy, A. C. Milner, S. M. Andrews, and C. F. Wellstead. 1998. Lepospondyli, Vol 1. Encylopedia of Paleoherpetology, P. Wellnhofer (ed.), Verlag Dr. Friedrich Pfeil, Munich, 216 p.

Clack, J. A. 2000. The origin of tetrapods, p. 979-1029. In H. Heatwole and R. L. Carroll (eds.), Amphibian Biology, Volume 4, Palaeontology: The Evolutionary History of Amphibians. Surrey Beatty \& Sons, Chipping Norton, NSW, Australia.

Clack, J. A., and R. L. Carroll. 2000. Early Carboniferous tetrapods, p. 1030-1043. In H. Heatwole and R. L. Carroll (eds.), Amphibian Biology Volume 4, Palaeontology: The evolutionary history of amphibians. Surrey Beatty \& Sons, Chipping Norton, NSW, Australia.

Clack, J. A., AND M. I. CoAtes. 1995. Acanthostega gunnari, a primitive aquatic tetrapod? Bulletin du Muséum national d'historie naturelle, 17:359-372.

Clarkson, E. N. K., A. R. Milner, And M. I. Coates. 1994. Palaeoecology of the Viséan of East Kirkton, West Lothian, Scotland. Transactions of the Royal Society of Edinburgh, 84:417-425.

CoATES, M. I. 1996. The Devonian tetrapod Acanthostega gunneri Jarvik: Postcranial anatomy, basal tetrapod interrelationships and pattern of skeleton evolution. Transactions of the Royal Society of Edinbugh: Earth Science, 87:363-421.

Coates, M. I., AND J. A. Clack. 1995. Romer's gap: Tetrapod origins and terrestriality. Bulletin du Muséum National d'Historie Naturelle, 17:373-388.

Cote, S., R. Carroll, R. Cloutier, and L. Bar-Sagi. In press. Vertebral development in the Devonian sarcopterygian fish Eusthenopteron foordi and the polarity of vertebral evolution in non-amniote tetrapods. Journal of Vertebrate Paleontology. 
DARwIN, C. 1859. On the Origin of Species by Means of Natural Selection. Murray, London, $502 \mathrm{p}$.

Daeschler, E. B., N. H. Shubin, K. S. Thomson, and W. W. Amaral. 1994. A Devonian tetrapod from North America. Science, 265:639642.

DiMichele, W. A., AND R. W. Hook. 1992. Paleozoic terrestrial ecosystems, p. 205-325. In A. K. Behrensmeyer, J. D. Damuth, W. A. DiMichele, R. Potts, H.-D Sues, and S. L. Wing (eds.), Terrestrial Ecosystems through Time. University of Chicago Press, Chicago.

GaO, K.-Q., And N. H. Shubin. 2001 Late Jurassic salamanders from northern China. Nature, 410:574-577.

GeHring, W. J. 1998. Master Control Genes in Development and Evolution: The Homeobox Story. Yale University Press, Yale, 236 p.

GiNGERICH, P. D. 1993. Quantification and comparison of evolutionary rates. American Journal of Science, 293A:453-478.

Heatwole, H., and R. L. Carroll (eds.). 2000. Amphibian Biology, Volume 4, Palaeontology: The Evolutionary History of Amphibians. Surrey Beatty \& Sons, Chipping Norton, NSW Australia.

HANKEN, J. 1984. Miniaturization and its effects on cranial morphology in plethodontid salamanders, genus Thorius (Amphibia: Plethodontidae), I, osteological variation. Biological Journal, Linnean Society, 23: $55-75$.

Holmes, R. 2000. Palaeozoic temnospondyls, p. 1081-1120. In H. Heatwole and R. L. Carroll (eds.), Amphibian Biology, Volume 4, Palaeontology: The Evolutionary History of Amphibians. Surrey Beatty \& Sons, Chipping Norton, NSW, Australia.

JARVIK, E. 1996. The Devonian tetrapod Ichthyostega. Fossils \& Strata, 40:1-213.

Jenkins, F. A., JR., AND N. H. ShubIN. 1998. Prosalirus bitis and the anuran caudopelvic mechanism. Journal of Vertebrate Paleontology, 18: 495-510.

JENKINS, F. A., JR., AND D. WALSH. 1993. An Early Jurassic caecilian with limbs. Nature, 365:246-250.

LAUDER, G. V., AND H. B. SCHAFFER. 1985. Functional morphology of the feeding mechanism in aquatic ambystomatid salamanders. Journal of Morphology, 185:297-326.

LaURIN, M. 2000. Seymouriamorphs, p. 1064-1080. In H. Heatwole and R. L. Carroll (eds.), Amphibian Biology, Volume 4, Palaeontology: The Evolutionary History of Amphibians. Surrey Beatty \& Sons, Chipping Norton, NSW, Australia, pp. 973-1496.

LAURIN, M., AND R. R. ReISZ. 1997. A new perspective on tetrapod phylogeny, p. 9-59. In S. S. Sumida and K. L. M. Martin (eds.), Amniote Origins. Academic Press, San Diego.

Lebedev, O. A., AND M. I. CoAtes. 1995. The postcranial skeleton of the Devonian tetrapod Tulerpeton curtum, Lebedev. Zoological Journal Linnean Society, London, 114:307-348.
LoFsvold, E. 1988. Quantitative genetics of morphological differentiation in Peromyscus: II. Analysis of selection and drift. Evolution, 42: $54-67$.

LonG, J. A. 1993. Palaeozoic Vertebrate Biostratigraphy and Biogeography. The Johns Hopkins University Press, Baltimore, 369 p.

MiLNER, A. C. 1994. The aïstopod amphibians from the Viséan of East Kirkton, West Lothian, Scotland. Transactions of the Royal Society of Edinburgh, 84:363-368.

Milner, A. R. 1982. Small temnospondyl amphibians from the Middle Pennsylvanian of Illinois. Palaeontology, 25:635-664.

MiLner, A. R. 1993. The Paleozoic relatives of lissamphibians. Herpetological Monographs, 7:8-27.

MiLnER, A. R. 2000. Mesozoic and Tertiary Caudata and Albanerpetontidae, p. 1412-1444. In H. Heatwole and R. L. Carroll (eds.), Amphibian Biology, Volume 4, Palaeontology: The Evolutionary History of Amphibians. Surrey Beatty \& Sons, Chipping Norton, NSW, Australia.

Milner, A. R., And S. E. K. Seoueira. 1994. The temnospondyl amphibians from the Viséan of East Kirkton, West Lothian, Scotland. Transactions of the Royal Society of Edinburgh, 84:331-361.

Paton, R. L., T. R. Smithson, AND J. A. Clack. 1999. An amniote-like skeleton from the Early Carboniferous of Scotland, Nature 398:508513.

RočEK, Z., J.-C. RAGe. 2000. Proanuran stages (Triadobatrachus, Czatkobatrachus), p. 1283-1294. In H. Heatwole and R. L. Carroll (eds.), Amphibian Biology, Volume 4, Palaeontology: The Evolutionary History of Amphibians. Surrey Beatty \& Sons, Chipping Norton, NSW, Australia.

Rolfe, W. D. I., E. N. K. Clarkson, And A. L. Panchen (eds.). 1994 Volcanism and early terrestrial biotas. Transactions of the Royal Society of Edinburgh, Earth Sciences, 84:175-464.

Shubin, N., C. TABIN, AND S. CARroll. 1997. Fossils, genes, and the evolution of animal limbs. Nature, 388:639-646.

Smithson, T. R., R. L. Carroll, A. L. Panchen, and S. M. Andrews, 1994. Westlothiana lizziae from the Viséan of East Kirkton, West Lothian, Scotland, and the amniote stem. Transactions of the Royal Society of Edinburgh, Earth Sciences, 84:383-412.

Wake, D. B., And N. Shubin. 1997. Limb development in the Pacific giant salamander, Dicamptodon (Amphibia, Caudata, Dicamptodontidae). Canadian Journal of Zoology, 76:2058-2066.

WARREN, A. 2000. Secondarily aquatic temnospondyls of the Upper Permian and Mesozoic, p. 1121-1149. In H. Heatwole and R. L. Carroll (eds.), Amphibian Biology, Volume 4, Palaeontology: The Evolutionary History of Amphibians. Surrey Beatty \& Sons, Chipping Norton, NSW, Australia.

ZitTel, K. A. von. 1890. Handbüch der Palaeontologie, III, Band Vertebrata (Pisces, Amphibia, Reptilia, Aves). Munich, 900 p.

ACCEPTED 5 MAY 2001 